\title{
Hydrobiochemical balance of total mercury in a forest catchment area at former cinnabar mining locality
}

\author{
L’udmila Mačejná $^{1,2}$, Andrea Zacharová ${ }^{\text {, Hana Ollerová }}{ }^{1}$, Jana Škvareninová1, Jaroslav Škvarenina ${ }^{2 *}$ \\ ${ }^{1}$ Faculty of Ecology and Environmental Sciences, Technical University in Zvolen, T. G. Masaryka 24, Zvolen, 960 01, Slovakia. \\ E-mails: ludmila.pliestikova@gmail.com; andrea.zacharova@tuzvo.sk; ollerova@tuzvo.sk; skvareninova@tuzvo.sk \\ ${ }^{2}$ Faculty of Forestry, Technical University in Zvolen, T. G. Masaryka 24, Zvolen, 960 01, Slovakia. E-mail: jaroslav.skvarenina@tuzvo.sk \\ * Corresponding author. E-mail: jaroslav.skvarenina@tuzvo.sk
}

\begin{abstract}
We studied the hydrobiochemical balance of total mercury (THg) in a forest ecosystem covering an area affected by mining activity in the past $\left(14^{\text {th }}-18^{\text {th }}\right.$ cent.) in the Kremnické vrchy Mts. (central Slovakia). A reference plot was located in an undisturbed area very close to primeval forest of Badínsky prales natural reserve. We analysed THg in bulk precipitation, throughfall, litterfall, forest floor percolate, forest soil and assimilatory organs of tree species. Results pointed out to high wet mercury deposition at both plots $\left(51 \mu \mathrm{g} \cdot \mathrm{m}^{-2} \cdot \mathrm{yr}^{-1}\right.$ an area near a cinnabar mining (MP1) and $37 \mu \mathrm{g} \cdot \mathrm{m}^{-2} \cdot \mathrm{yr}^{-1}$, in a reference catchment area near the protected primary forest (MP2)) as well as high THg deposition by throughfall $\left(74 \mu \mathrm{g} \cdot \mathrm{m}^{-2} \cdot \mathrm{yr}^{-1}\right.$ and $51 \mu \mathrm{g} \cdot \mathrm{m}^{-2} \cdot \mathrm{yr}^{-1}$, respectively in MP1 and MP2). Litterfall does not represent the main THg flux into forest soil but together with throughfall doubles the THg input compared to open space deposition. Forest ecosystem has ability to capture atmospheric $\mathrm{Hg}$ and thus makes new sources of mercury inputs (throughfall and litterfall) into soil.
\end{abstract}

Keywords: Total mercury; Bulk precipitation; Throughfall; Litterfall; Wet deposition; Forest; Cinnabar mining.

\section{INTRODUCTION}

Mercury $(\mathrm{Hg})$ is a ubiquitous toxic element present at trace concentrations in the environment. Its chemical forms, mobilization and redistribution are influenced by both abiotic and biotic processes. On the basis of its physical and chemical properties the cycling of mercury involves a complex set of chemical, biological, and physical transformations, including biotic and abiotic methylation and demethylation, volatilization, photoreduction, photooxidation, and adsorption. Although the interactions between soil - vegetation - atmosphere consist of a complex set of bi-directional fluxes (Lindberg, 1996), there is a strong limitation of root mercury uptake that atmospheric $\mathrm{Hg}$ is the almost exclusive source of $\mathrm{Hg}$ in vegetation (Grigal, 2003).

The majority of gaseous elemental mercury (GEM) has a lifetime from 2.7 months to 2 yrs due to its low solubility and high volatility (e.g. Wright et al., 2016; Zhou et al., 2018). Atmospheric mercury in the gas phase and in aerosols is deposited onto plant surfaces and can be assimilated into plant tissues through the leaf stomata (Lindberg et al., 1992; Rea et al., 1996). Foliage surface can absorb also particulate-bound (PBM) $\mathrm{Hg}$ (Fu et al., 2015). Part of $\mathrm{Hg}$ accumulated in the foliage could originate from evasion from the soil (Gustin and Stamenkovic, 2005; Gustin et al., 2006).

Studies reported that wet and dry depositions of atmospheric $\mathrm{Hg}$ are important sources of $\mathrm{Hg}$ in terrestrial ecosystems (e.g. Zhou et al., 2020). Dry deposition of $\mathrm{Hg}$ to forest canopy followed by throughfall and litterfall represents an additional source of Hg to forest (Blackwell and Driscoll, 2015b; Zhou et al., 2018). Mercury in throughfall is a part of the internal cycling of $\mathrm{Hg}$ in forests ecosystems and includes wet-deposited $\mathrm{Hg}$ above the canopy and a portion of dry-deposited $\mathrm{Hg}$ washed off from the canopy (Wright et al., 2016). Throughfall represents particularly washed off PBM and gaseous oxidized mercury (GOM) (Rea et al., 2001). Most authors consider litterfall as the most important flux of mercury to the forest floor (Rea et al., 2002; Schwesig and Matzner, 2001; St. Louis et al., 2001; Zhou et al., 2020). Concentration of mercury in litterfall is affected by tree species (anatomic and morphologic characteristics of foliage and its lifespan) as well as environmental factors (microclimatic and site characteristics) (Zhou et al., 2017). Due to these existing fluxes the deposition of $\mathrm{Hg}$ to the forest floor can be two or three times higher as on the open field (areas without forest vegetation) (Kolka et al., 2001; St. Louis et al., 2001). Existence of these mercury fluxes makes forest ecosystems a large sink of atmospheric $\mathrm{Hg}$ and an active pool of mercury with an important role in global mercury cycle (Zhou et al., 2020).

The aim of this study was to investigate the most important fluxes of total mercury $(\mathrm{THg})$ in two small forested catchment areas with different anthropogenic load in the Kremnické vrchy Mts. (Slovakia). One research area (MP1) was located in a small catchment area where mercury had been mined (as cinnabar). The locality belongs to the most polluted by mercury in central Europe due to mercury that is released from old mine waste heaps into environment. The second research area (MP2) represents a small reference catchment area with a relatively well-preserved environment near a protected primary forest.

\section{MATERIALS AND METHODS Study site description}

The plots MP1 and MP2 are situated in the Kremnické vrchy Mts., Slovakia (Fig. 1) the air distance between the plots is approximately $2.5 \mathrm{~km}$. The mean annual air temperature oscillates between 5.8 and $6.8^{\circ} \mathrm{C}$, together with annual precipitation of $920-980 \mathrm{~mm}$ shows that area belongs to cold mountainous climate-geographic type. Average growing season takes 120 - 140 days and average number of days with snow cover is 140 - 150 (Mind'áš and Škvarenina, 2001; Vido et al., 2016). 

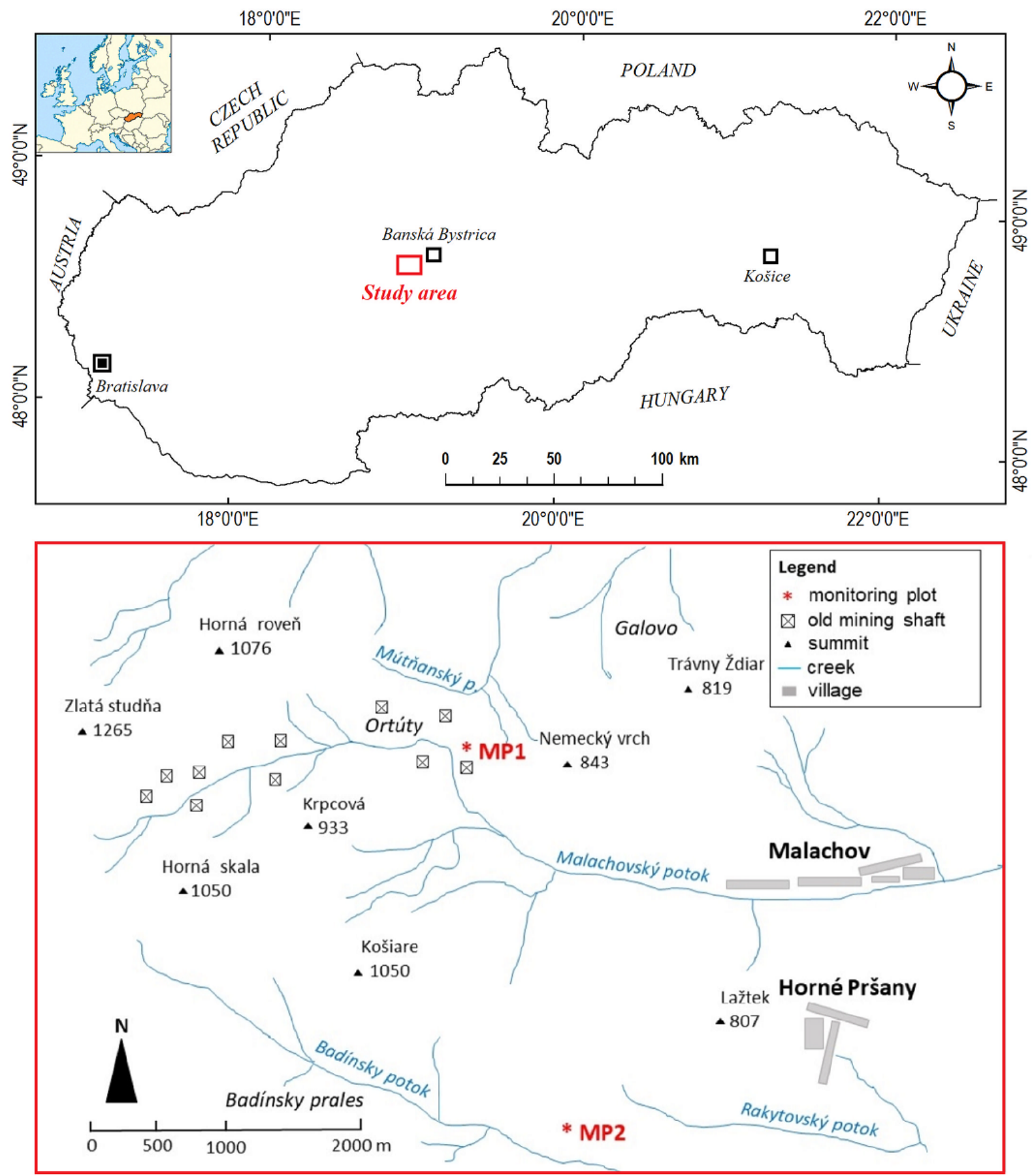

Fig. 1. Localization of monitoring plots.

From the geological perspective the plot MP1 $\left(19^{\circ} 02^{\prime} 51^{\prime \prime}\right.$ $\left.\mathrm{E} ; 48^{\circ} 42^{\prime} 59^{\prime \prime} \mathrm{N}\right)$ consists of dolomites, dolomitic limestones and volcanic rocks. This plot is located in a historic mining area of cinnabar $\mathrm{HgS}\left(14^{\text {th }}-18^{\text {th }}\right.$ centuries $)$ near village Malachov. The terrain condition is strong affected by historical mining activity (there are currently forested heaps from mine waste, depressions, exposed rocks, etc.). For this reason, an initial anthrosol was formed on this area. The MP1 area is located in the catchment area of the "Malachovský potok" stream. It is a right-hand tributary of the Hron River and has a length of 10.8 $\mathrm{km}$. The catchment area has about $16.16 \mathrm{~km}^{2}$, which $92 \%$ is covered by forest area, where the sampling was performed. The average long-term volumetric flow rate (years $1961-2000$ ) is $0.250 \mathrm{~m}^{3} \cdot \mathrm{s}^{-1}$ (Hlavčová et al., 2009). The elevation ranges from
715 to $730 \mathrm{~m}$ a.s.l. The forest at MP1 belongs to the $4^{\text {th }}$ beech (Fagus) altitudinal zone and the group of Fagetum typicum forest type according to Hančinský (1972), and Neutrophilous beech (Fagus) forests (Stanová and Valachovič, 2002). The European beech (Fagus sylvatica L.) is the dominant tree species, followed by Norway spruce (Picea abies (L.) Karst. and Austrian pine (Pinus nigra L.).

The bedrock of the MP2 plot (19 03' 34" E; $\left.48^{\circ} 41^{\prime} 35^{\prime \prime} \mathrm{N}\right)$ is formed by andesite conglomerates covered by lava flows of pyroxenic andesite with breccias (Bublinec and Pichler, 2001). The most common soil types are nutrient-rich and slightly acidic cambisols with a high production potential. The MP2 area is located in the adjacent catchment area of the "Badínsky potok" stream. It is a right-hand tributary of the Hron and have 
Hydrobiochemical balance of total mercury in a forest catchment area at former cinnabar mining locality

$11.2 \mathrm{~km}$ long. The basin has a high forest cover of about $97 \%$, especially in its upper parts. The catchment area is $11.18 \mathrm{~km}^{2}$. The average long-term flow (for the years 1961 - 2000) reaches the value of $0.155 \mathrm{~m}^{3} \cdot \mathrm{s}^{-1}$ (Hlavčová et al., 2009).

The MP2 plot belongs to the 4th beech (Fagus) altitudinal zone and group of forest types Fagetum pauper (Neutrophilous beech (Fagus) forests). The research plot is located near to the Badin Primary Forest. The tree species composition is very similar to the native forest stands. This forest is represented by Fagus sylvatica L., Picea abies (L.) Karst and Abies alba L. (Jaloviar et al., 2017; Kucbel et al., 2010; Pichler et al., 2012). The elevation ranges from 725 to $740 \mathrm{~m}$ a.s.l.

\section{Sampling of precipitation and throughfall}

Vertical precipitation was collected on MP1 and MP2 in the open area (e.g. FA1 and FA2) at a distance of $100-200 \mathrm{~m}$ from the forest using a polyethylene collector made of chemically inert material to rainwater with a catchment area of 200 $\mathrm{cm}^{2}$.

Throughfall was collected with same polyethylene containers as vertical precipitation. The collection vessels consisted of a dark borosilicate glass bottle $(250 \mathrm{ml})$ placed in a dark polyethylene container. There were placed three collectors on both experimental surfaces. On MP1, collectors were placed under Fagus sylvatica, Picea abies and Pinus nigra and on MP2 under Fagus sylvatica, Picea abies and Abies alba. Average throughfall represents the average value of concentrations of throughfall of beech, spruce, pine or fir from the same locality.

Methodology of sampling of precipitation and throughfall for the purpose of determining $\mathrm{THg}$ was used according to works (Schwesig and Matzner, 2000; 2001). Collectors were placed in the beginning of April till the end of the year. Sampling was done in two-weeks interval from April to Dec. over one year.

\section{Soil samples and forest floor percolate sampling}

Soil samples were taken from individual soil horizons according to STN 48 1000. A representative sample from the same soil horizon composed from 10 samples and then analysed. At both localities was made soil pit. At MP1 open area we identify horizon Ao, El, Btr and Btrg, in the forest just Adi and $\mathrm{C}$ horizon. At MP2 we identify $\mathrm{Au}, \mathrm{A} / \mathrm{B}$ and $\mathrm{Bv}$ horizons in forest as well as in open area.

Forest-floor percolate water was collected by means of plate gravity lysimeters (polyethylene tube connected to a polypropylene vessel, which was located in a covered pit) on both monitoring sites. At each monitoring plot were placed four lysimeters (at depths of 10 and $20 \mathrm{~cm}$ in forest as well as open area). The depth of lysimeter placement was determined based on the recommendations of authors (De Vries et al., 2005).

\section{Sampling of assimilatory organs and litterfall}

Assimilatory organs (leaves and needles) were sampled according to STN 48 1001. Representative sample consists of several individual samples. Foliage of deciduous trees (Fagus sylvatica L., Corylus avellana L.) were collected at both localities in two-week intervals (from April to October). The assimilation organs of coniferous trees (Picea abies (L.) Karst., Pinus nigra Arnold, Abies alba Mill.) were sampled in autumn. Needles were sorted according to individual years.

Litter was collected in proper collectors, which consisted of funnels made of high-density polyethylene with an upper diam- eter of $70 \mathrm{~cm}$. In both localities, three collectors were placed in the forest at a height of $1 \mathrm{~m}$ above the earth's surface. Litterfall was sampled in two weeks from April to the middle of Nov. over one growing season.

\section{Sample preparation and mercury analysis}

$\mathrm{THg}$ in liquid samples were stabilized by added $2 \mathrm{ml}$ of $\mathrm{HCl}$ p.a. $(35 \%)$ to the sample vessels. The collected liquid samples were filtered before the analysis due to remove mechanical impurities from the samples.

Unwashed samples of litter and assimilation organs were dried at room temperature. Dried samples were ground and homogenized with a ball mill MM1 301.

Soil samples were also dried at room temperature, cleaned of organic impurities, sieved through a sieve with mesh size of $2 \mathrm{~mm}$ to gain a finesoil.

Liquid and solid samples were determined by single-purpose atomic absorption spectrometer for mercury determination without sample mineralization (AMA 254, Altec, Czech Republic). The accuracy of the results was checked at the beginning of each measurement by measuring certified reference materials and measuring deionized water. The AMA 254 spectrometer has detection limit $0.01 \mathrm{ng} \mathrm{Hg}$ and high repeatability $(<1.5 \%)$. The volume of liquid sample was $200(400) \mu \mathrm{l}$ and the weight of the solid sample was in the range $40-60 \mathrm{mg}$. The analyses were done under the determination times for liquid samples $45 \mathrm{~s}, 120 \mathrm{~s}$ and $45 \mathrm{~s}$ for drying, decomposition and stabilization, respectively and $60 \mathrm{~s}, 180 \mathrm{~s}, 45 \mathrm{~s}$ in the case of assimilatory organs. Each sample was analysed at least three times in parallel with rsd lower than $10 \%$.

\section{Data analysis}

Mathematical-statistical methods were used to evaluate experimental data, in particular processing of statistical characteristics of measured data, application of regression and correlation analysis, one-way analysis of variance (ANOVA) and hypothesis testing. For these purp oses, we used standard methods of mathematical statistics (Scheer, 2007; Šmelko and Wolf, 1977) and tools in Excel and Statistica 6.

Deposition of $\mathrm{THg}$ via precipitation (wet deposition) on open space and in forest was calculated according to the:

$D P_{w}=C_{w} \cdot P_{w}$

where $D P_{w}=$ wet deposition $\left(\mu \mathrm{g} \cdot \mathrm{m}^{-2}\right), C_{w}=\mathrm{THg}$ concentration in precipitation (rainwater) $\left(\mu \mathrm{g} \cdot \mathrm{l}^{-1}\right), P_{w}=$ precipitation $(\mathrm{mm})$.

$\mathrm{THg}$ runoff into lower soil layers on open space and in the forest was calculated according to the:

$O=C_{p r} \cdot O_{p r}$

where $O=\mathrm{THg}$ runoff into lower soil layers $\left(\mu \mathrm{g} \cdot \mathrm{m}^{-2}\right), C_{p r}=$ $\mathrm{THg}$ concentration in forest-floor percolate $\left(\mu \mathrm{g} \cdot \mathrm{l}^{-1}\right), O_{p r}=$ total amount of lysimetric (percolate) water $(\mathrm{mm})$.

Deposition of $\mathrm{THg}$ via litterfall: was calculated according to the:

$D P_{A O}=C_{A O} \cdot \mathrm{P}_{\mathrm{AO}}$

where $D P_{A O}=\mathrm{THg}$ deposition through litterfall $\left(\mu \mathrm{g} \cdot \mathrm{m}^{-2}\right)$, $C_{A O}=\mathrm{THg}$ concentration in assimilatory organs (leaves and needles) $h\left(\mu \mathrm{g} \cdot \mathrm{g}^{-1}\right), P_{A O}=$ amount of litterfall $\left(\mathrm{g} \cdot \mathrm{m}^{-2}\right)$.

Storage of $\mathrm{THg}$ in soil $\left(\mathrm{mg} \cdot \mathrm{m}^{-2}\right)$ was calculated as c $(\mathrm{THg})$ in soil $\left(\mathrm{mg} \cdot \mathrm{kg}^{-1}\right) \cdot$ bulk density $\left(\mathrm{kg} \cdot \mathrm{m}^{-3}\right) \cdot$ soil depth $(\mathrm{m})$. 


\section{RESULTS}

\section{THg in bulk precipitation and throughfall}

Over the observed period, the total amount of precipitation on the open space and forested area MP1 was $954 \mathrm{~mm}$ and 821 $\mathrm{mm}$, respectively. At the MP2 site, $916 \mathrm{~mm}$ of rain fell down on the open space area and the total amount of throughfall was $567 \mathrm{~mm}$.

The course of $\mathrm{THg}$ concentration in precipitation and throughfall at localities MP1 and MP2 is shown in Fig. 2. The concentration of $\mathrm{THg}$ at MP1 in precipitation at the open space was $0.09 \pm 0.05 \mu \mathrm{g} \cdot \mathrm{l}^{-1}$. The throughfall reached values $0.15 \pm$ $0.07 \mu \mathrm{g} \cdot \mathrm{l}^{-1}$. At the MP2 site, precipitation and throughfall reached $0.07 \pm 0.04 \mu \mathrm{g} \cdot \mathrm{l}^{-1}$ and $0.16 \pm 0.07 \mu \mathrm{g} \cdot \mathrm{l}^{-1}$, respectively.

At both localities the $\mathrm{THg}$ concentrations in precipitation at open space compared to throughfall were significantly lower. We can conclude this with $95 \%$ confidence (Duncan test at the level $\alpha=0.05)$ at MP1 and with $99 \%$ confidence $(\alpha=0.01)$ at MP2.

Wet deposition of $\mathrm{THg}$ via throughfall at the MP1 site $\left(74 \mu \mathrm{g} \cdot \mathrm{m}^{-2}\right)$ was higher than deposition in the open space $\left(51 \mu \mathrm{g} \cdot \mathrm{m}^{-2}\right)$.

We used a nonlinear regression analysis to evaluate the effect of total precipitation on the THg concentration in the precipitation. Variance of $\mathrm{THg}$ concentration values in precipitation at open space depend on the amount of precipitation (75\% at MP1 and $73 \%$ at MP2). THg concentration values in the precipitation are dependent on the total precipitation $(80 \%$ at the MP1 site and $65 \%$ at the MP2 site). The correlation index (Iyx) expressing the relationship between the variables on the open space has a value of 0.87 (MP1) and 0.86 (MP2) and in the stand 0.90 (MP1) and 0.81 (MP2). The difference in $\mathrm{I}_{\mathrm{yx}}$ in the stand at the monitored localities MP1 and MP2 is due to the different tree species composition. The results of the correlation analysis indicate a high degree of inverse dependence between the concentration of $\mathrm{THg}$ in precipitation and the amount of precipitation. This relationship can be explained by the ability of precipitation to elute oxidized forms of $\mathrm{Hg}$ and $\mathrm{Hg}$ bound to particles at the beginning of the precipitation event (Downs et al., 1998).

\section{THg in assimilatory organs and litterfall}

At MP1, content of THg was analysed in assimilatory organs (leaves and needles) of beech (Fagus sylvatica), hazelnut (Corylus avellana), Norway spruce (Picea abies) and pine (Pinus nigra). Measured concentrations were in the range $0.011-$ $0.256 \mu \mathrm{g} \cdot \mathrm{g}^{-1}$. Very similar results were measured in leaves of beech (Fagus sylvatica) and hazelnut (Corylus avellana) as well as Norway spruce (Picea abies) and fir (Abies alba) at MP2, $0.008-0.248 \mu \mathrm{g} \cdot \mathrm{g}^{-1}$ (Fig. 3).

The total THg deposition through the litterfall in the stand at MP1 was $26.9 \mu \mathrm{g} \cdot \mathrm{m}^{-2}$. At the MP2 site, the THg input via litterfall represents $22.9 \mu \mathrm{g} \cdot \mathrm{m}^{-2}$ (Table 1 ).

The concentration of THg in litterfall at the MP1 site (beech + spruce + pine) ranged between $0.036-0.589 \mu \mathrm{g} \cdot \mathrm{g}^{-1}$ and at MP2 (beech + spruce + fir) it was in the range of $0.035-0.129$ $\mu \mathrm{g} \cdot \mathrm{g}^{-1}$. Based on the results of the Duncan test, it can be concluded that the difference in $\mathrm{THg}$ concentrations in the litterfall at both monitoring plots is random.

Using linear regression analysis, we analysed relationship between $\mathrm{THg}$ deposition through litterfall and $\mathrm{THg}$ concentration in litter and likewise between litterfall $\mathrm{THg}$ deposition and the total amount of litterfall. Based on the results (Figures 4 and 5), it can be concluded that the mass of $\mathrm{THg}$ deposition through the litterfall depends only on the amount of the litterfall mass per surface unit (MP1: $r=0.87, p<0.001 ; M P 2: r=0.99$, $\mathrm{p}<0.001$ ).

\section{THg in soil and forest soil percolate}

At the open space MP1 site, the concentration of $\mathrm{THg}$ in soils ranged from 0.400 to $1.809 \mu \mathrm{g} \cdot \mathrm{g}^{-1}$. In the forest area (FA1), the THg concentrations in soils were higher by a few orders of magnitude compared to the values in the open area $\left(155-235 \mu \mathrm{g} \cdot \mathrm{g}^{-1}\right)$. This tremendous difference is the most probably due to inhomogeneity of the subsoil caused by historical mining. At the MP2 site (FA2), the concentration of THg in the soil ranged from 0.140 to $0.176 \mu \mathrm{g} \cdot \mathrm{g}^{-1}$ (open area) and 0.217 to $0.346 \mu \mathrm{g} \cdot \mathrm{g}^{-1}$.

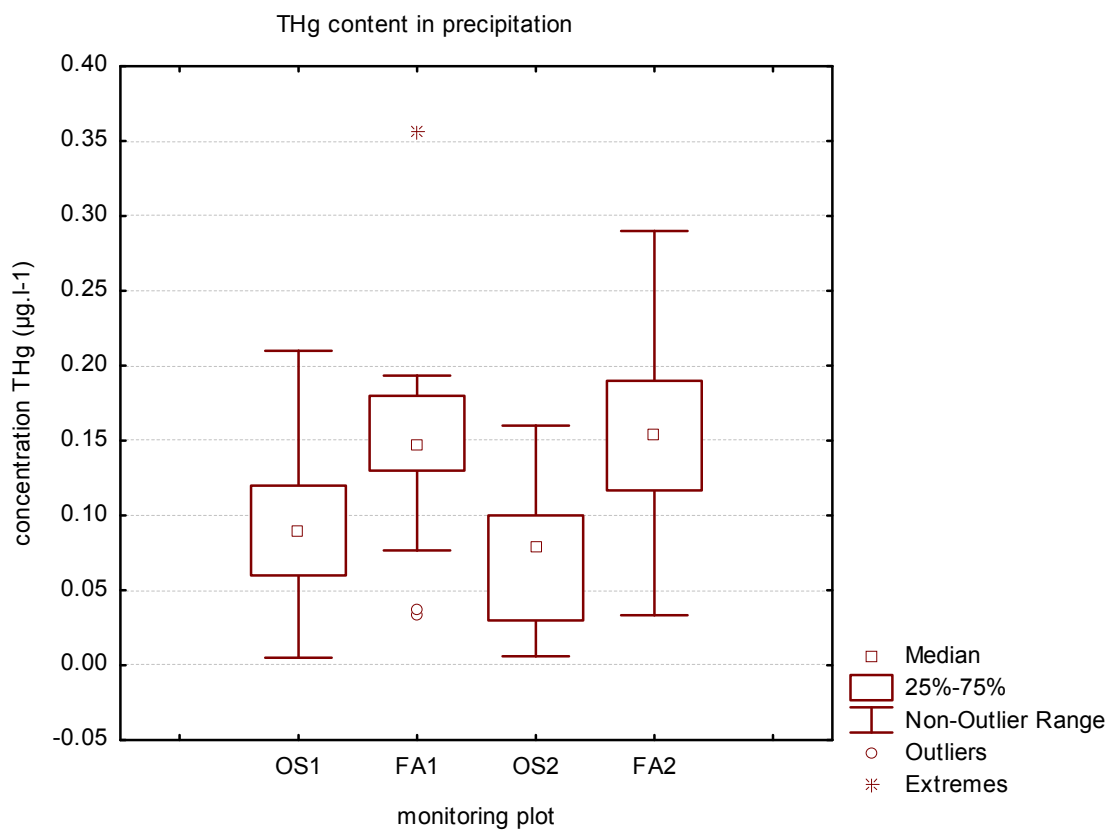

Fig. 2. Concentration of THg in precipitation and throughfall at monitoring plots (OS1 - open space in MP1 Malachov; FA1 - forest area in MP1 Malachov; OS2 - open space in MP2 Badín; FA2 - forest area in MP2 Badín). 


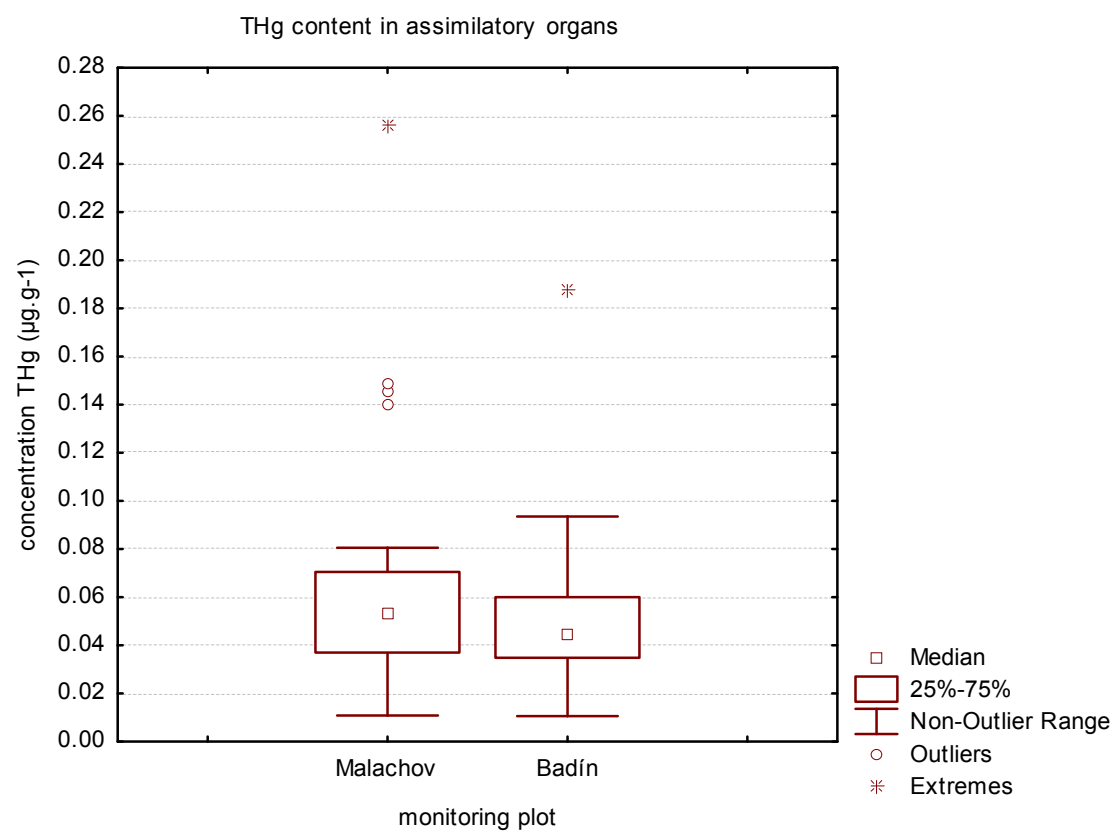

Fig. 3. Concentration of THg in assimilatory organs at monitoring plots (MP1 = Malachov; MP2 = Badín).

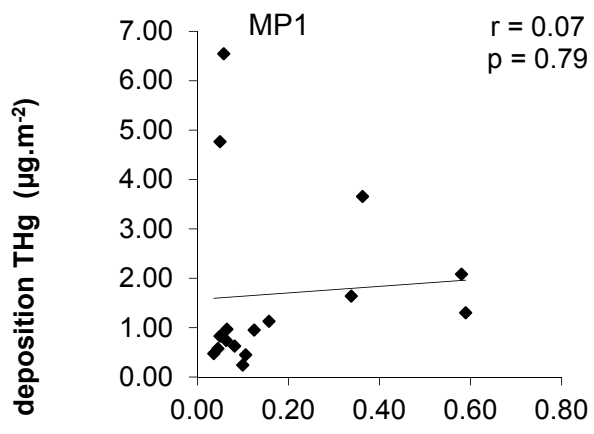

THg concentration $\left(\mu \mathrm{g} \cdot \mathrm{g}^{-1}\right)$

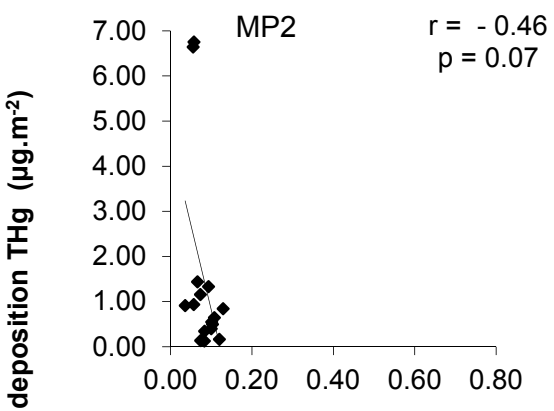

THg concentration $\left(\mu \mathrm{g} \cdot \mathrm{g}^{-1}\right)$

Fig. 4. Relationship between THg concentration in litterfall and THg deposition through litterfall.
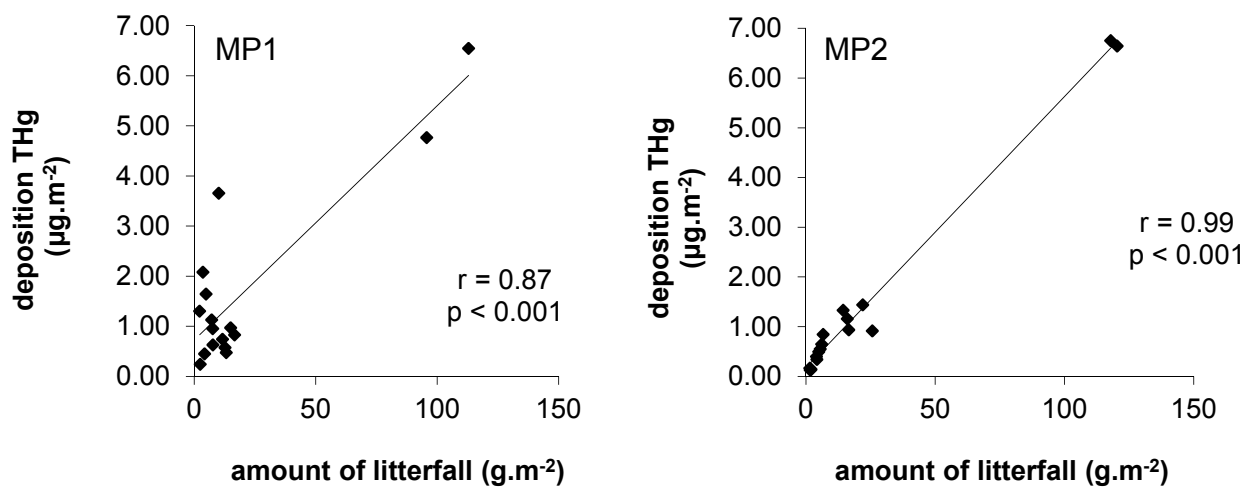

Fig. 5. Relationship between litterfall amount and THg deposition through litterfall.

Table 1. Mean THg concentration in litterfall and THg fluxes through litterfall at monitoring plots.

\begin{tabular}{lllll}
\hline Monitoring plot & Total amount of litterfall & \multicolumn{2}{l}{ Mean THg concentration in litterfall } & THg flux through litterfall \\
\hline & $\mathrm{g} \cdot \mathrm{m}^{-2}$ & $\mu \mathrm{g} \cdot \mathrm{g}^{-1}$ & $\mathrm{~N}$ & $\mu \mathrm{g} \cdot \mathrm{m}^{-2}$ \\
MP1 & 327 & 0.17 & 48 & 27 \\
MP2 & 368 & 0.08 & 48 & 23 \\
\hline
\end{tabular}




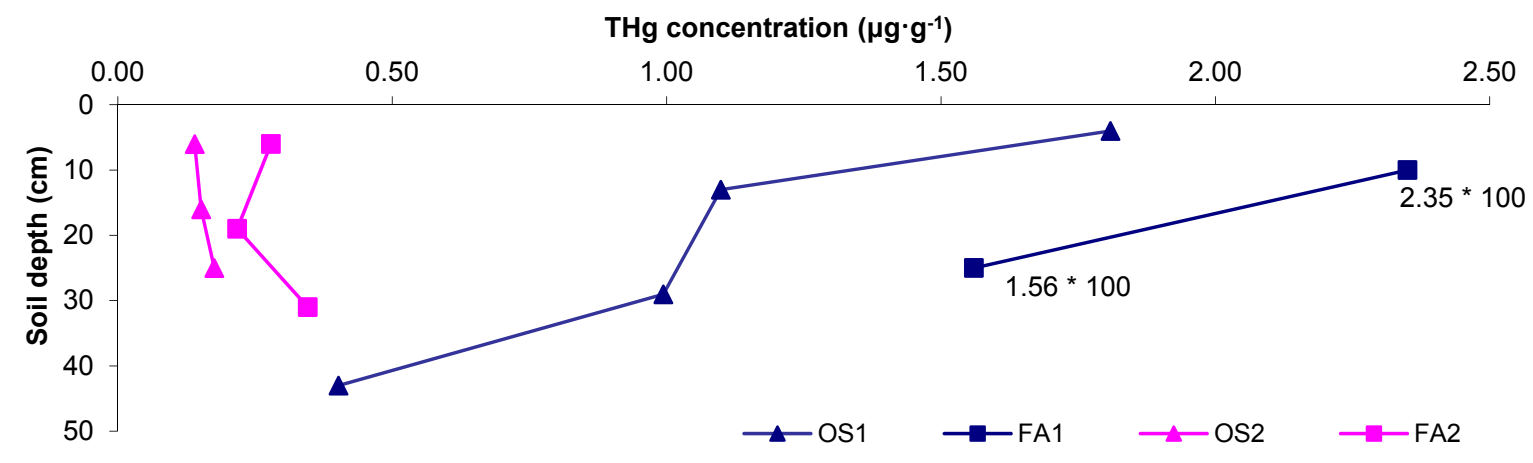

Fig. 6. Distribution of THg in soil (OS1 - open space in MP1 Malachov; FA1 - forest area in MP1 Malachov; OS2 - open space in MP2 Badín; FA2 - forest area in MP2 Badín).

The course of THg content in soil profile at monitoring sites is shown in Fig. 6. Mercury concentration decreases with depth in the soil at the MP1 site. The high concentration of $\mathrm{THg}$ $\left(156-235 \mu \mathrm{g} \cdot \mathrm{g}^{-1}\right)$ in the forest is caused by the cinnabar presence $(\mathrm{HgS})$.

The higher content of $\mathrm{THg}$ in the umbric soil horizon $\mathrm{Au}$ in the forest (MP2) compared with the open area is probably caused by the flow of $\mathrm{Hg}$ into the soil through the litterfall and throughfall. Subsequently, this mercury enters the lower A / B horizon by elution. At the open area, the THg content was the lowest in the upper Au horizon and gradually increased with the depth. The source of $\mathrm{Hg}$ in the upper layer of the soil is only atmospheric deposition (wet and dry), which is, however, smaller than at the MP1 site.

In MP1 area concentrations of $\mathrm{THg}$ in percolate varied in similar ranges in both open space and forested areas $(0.02-$ $0.25 \mu \mathrm{g} \cdot \mathrm{l}^{-1}$ and $0.09-0.33 \mu \mathrm{g} \cdot \mathrm{l}^{-1}$, respectively). In MP2 site the $\mathrm{THg}$ concentrations in percolate were slightly lower but in the same order of magnitude $\left(0.02-0.18 \mu \mathrm{g} \cdot \mathrm{l}^{-1}\right.$ in open space and $0.05-0.22 \mu \mathrm{g} \cdot \mathrm{l}^{-1}$ in forest area).

The runoff of THg to the lower soil layers in the open area at the MP1 site at a depth of $10 \mathrm{~cm}$ was $39.2 \mu \mathrm{g} \cdot \mathrm{m}^{-2}$ and the runoff from a soil depth of $20 \mathrm{~cm}$ was $22.8 \mu \mathrm{g} \cdot \mathrm{m}^{-2}$. In the forest, the runoff of THg from the soil layer of $10 \mathrm{~cm}$ and $20 \mathrm{~cm}$ was $32.4 \mu \mathrm{g} \cdot \mathrm{m}^{-2}$, and $52 \mu \mathrm{g} \cdot \mathrm{m}^{-2}$, respectively.

At the MP2 site, runoff from the layer $10 \mathrm{~cm}$ represents 29.7 $\mu \mathrm{g} \cdot \mathrm{m}^{-2}$ at the open space and $24.2 \mu \mathrm{g} \cdot \mathrm{m}^{-2}$ from the $20 \mathrm{~cm}$ soil layer. In the forest, runoff reached $28 \cdot 3 \mu \mathrm{g} \cdot \mathrm{m}^{-2}$ in depth $10 \mathrm{~cm}$ and $18.8 \mu \mathrm{g} \cdot \mathrm{m}^{-2}$ from $20 \mathrm{~cm}$ soil layer.

Between the concentration of $\mathrm{THg}$ in the percolate at the depth of $10 \mathrm{~cm}$ and $20 \mathrm{~cm}$ at the open space of MP1 is a correlation (Pearson coefficient MP1 r $=0.95$ and MP2 $r=0.91$ ). In the forest on both sites content of $\mathrm{THg}$ in the percolate at a depth of 10 and $20 \mathrm{~cm}$ is equally high (MP1 r $=0.89$, MP2 $\mathrm{r}=$ $0.86)$.

\section{Hydrobiochemical balance and THg fluxes}

Based on the obtained quantitative and qualitative characteristics of precipitation, lysimetric waters, biomass and soil, we made calculation of depositions, or substance flows and $\mathrm{THg}$ reserves in the components of the environment for both investigated localities (Fig. 7 and 8). The input $\mathrm{THg}$ flows represent mainly throughfall and litterfall. Due to high concentration of $\mathrm{THg}$ in the soil at MP1, we considered the weathering of cinnabar $\left(8.5 \mu \mathrm{g} \cdot \mathrm{m}^{-2}\right.$ according to Beneš (1994) as input THg to soil.
The output THg flows in the forest ecosystem represent the $\mathrm{THg}$ runoff from the upper $10 \mathrm{~cm}$ layer of soil to the deeper parts of the soil as well as the intake of THg by the plant root system. The flow of THg into the soil through the litterfall is balanced between individual localities and it is lower than via throughfall.

\section{DISCUSSION \\ THg flux via wet deposition}

The concentration of $\mathrm{THg}$ at MP1 in precipitation at the open space was in the range $0.01-0.21 \mu \mathrm{g} \cdot \mathrm{l}^{-1}$ and in the throughfall reached values $0.03-0.36 \mu \mathrm{g} \cdot 1^{-1}$. At the MP2 site, precipitation and throughfall ranged $0.01-0.16 \mu \mathrm{g} \cdot \mathrm{l}^{-1}$ and $0.03-0.29 \mu \mathrm{g} \cdot \mathrm{l}^{-1}$, respectively. Measured values are much lower than notes e.g. Wang et al. (2016) from European and North American remote temperate/boreal forests (5.9 - 19.0 $\left.\mu \mathrm{g} \cdot \mathrm{l}^{-1}\right)$.

There is very difficult to compare $\mathrm{THg}$ concentration in precipitation from because it is affected by occurrence of $\mathrm{Hg}$ pollution source, ambient air mercury species and their content varies in season and individual precipitation event (Cole et al., 2014). Much $\mathrm{Hg}$ in precipitation comes from cloud scavenging (Malcom et al., 2003; Zhou et al., 2018). Simulation shows that stratiform cloud scavenging is lower than in thunderstorms and that in-cloud scavenging is more efficient comparing to below cloud scavenging (Nair et al., 2013). Studies suggested that $\mathrm{THg}$ in precipitation are originated from the scavenging of PBM and GOM in the atmosphere (Zhou et al., 2013). There is also difference between PBM content in snow and non-snow precipitation (Faïn et al., 2011). More than $95 \%$ of $\mathrm{THg}$ in atmosphere in forest areas is in GEM form which is fairly stable in the lower atmosphere, with limited solubility and cannot be scavenged from atmosphere via wet deposition (Zhou et al., 2020). Mercury associated with airborne particulate matters can reach up to various components of the environment. Besides that, TPM (total particulate mercury) may be deposited together with the particulate matter within dry or wet deposition. These are mechanisms of self-cleaning up of the atmosphere. As a result of these processes, the concentration of mercury increases in forests, soils, rivers, etc. (Styszko et al., 2015). Among the most polluted places are those located in mountain valleys. Research on the impact of meteorological conditions on particulate concentrations in the air has shown a clear relationship between elevated concentrations and thermal inversion mainly in winter season (Zuśka et al., 2019). 


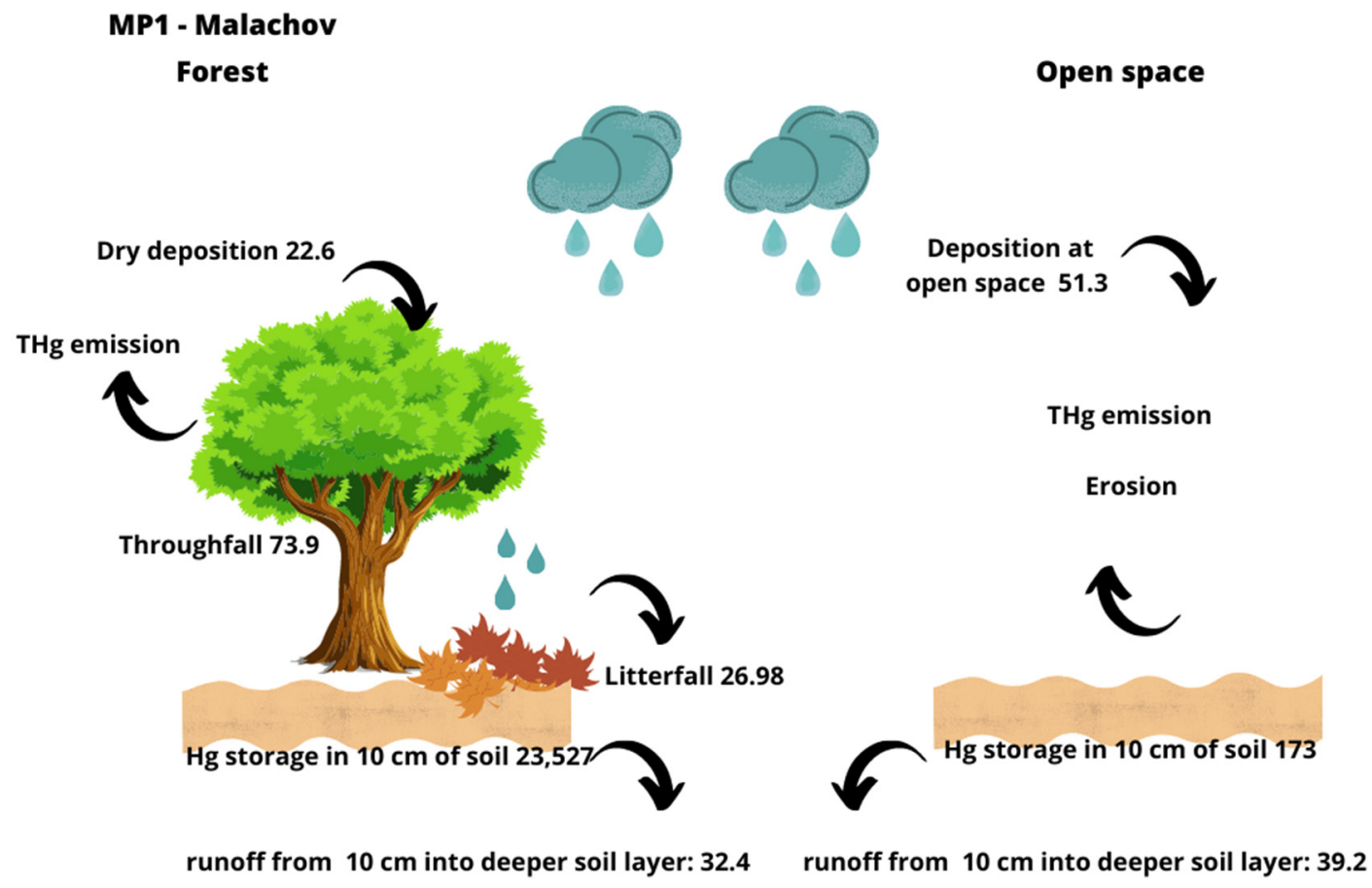

Fig. 7. Mercury flux $\left(\mu \mathrm{g} \cdot \mathrm{m}^{-2} \cdot \mathrm{yr}^{-1}\right)$ and $\mathrm{THg}$ storage $\left(\mathrm{mg} \cdot \mathrm{m}^{-2}\right)$ at MP1.

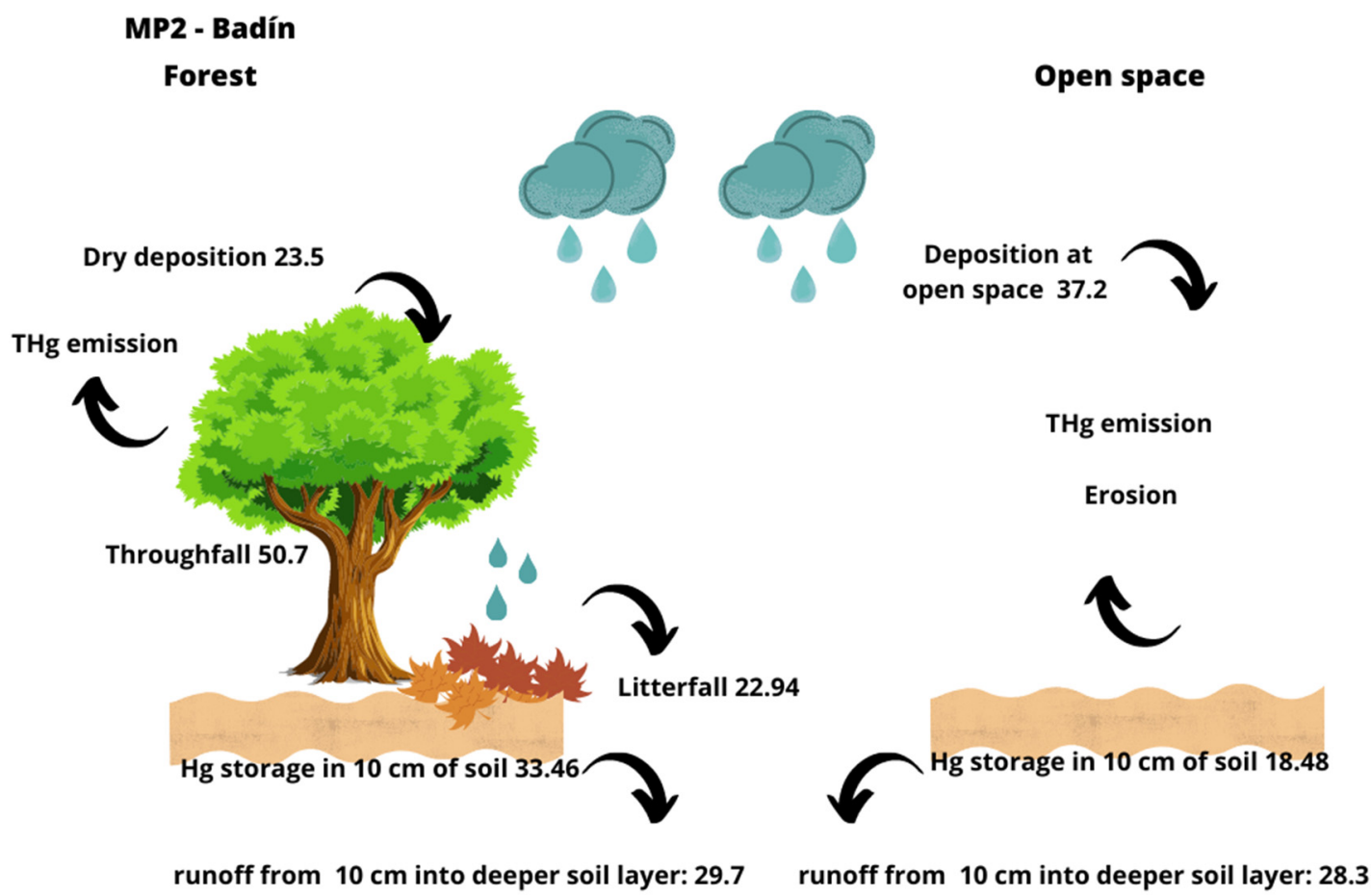

Fig. 8. Mercury flux $\left(\mu \mathrm{g} \cdot \mathrm{m}^{-2} \cdot \mathrm{yr}^{-1}\right)$ and $\mathrm{THg}$ storage $\left(\mathrm{mg} \cdot \mathrm{m}^{-2}\right)$ at MP2.

\section{THg flux via litterfall and comparision to throughfall}

Studies shows $\mathrm{THg}$ concentration in litterfall in the range from 0.045 to $0.063 \mu \mathrm{g} \cdot \mathrm{g}^{-1}$ in temperate remote deciduous forest (Zhou et al., 2017) and from Europe set range approx. $0.005-0.042 \mu \mathrm{g} \cdot \mathrm{g}^{-1}$ (Blackwell and Driscoll, 2015b; Wright et al., 2016; Zhou et al., 2020), which are much lower than our mean concentrations $0.17 \mu \mathrm{g} \cdot \mathrm{g}^{-1}$ and $0.08 \mu \mathrm{g} \cdot \mathrm{g}^{-1}$ at the MP1 and MP2 site, respectively. Petráš et al. (2012) evaluated mercury contents in poplar clones biomass from riparian lowland forest (forest stands of the Danube Lowland and the EastSlovak Lowland near the rivers Danube and Latorica). They 
published average $\mathrm{Hg}$ values $0.04 \mu \mathrm{g} \cdot \mathrm{g}^{-1}$ in "small woods" (branches of trees with a diameter $<7 \mathrm{~cm}$ ). Mercury is also known for its affinity to humus particles and water sediments, where is deposited in increased rate and is transformed into organic form as methylmercury ( $\mathrm{MeHg}$ ). In contrast to $\mathrm{Hg}^{-\mathrm{II}}$, $\mathrm{MeHg}$ is easily and rapidly exchanges one thiol group for another, which explains why methylmercury spreads more easily through internal plant tissues than inorganic $\mathrm{Hg}^{-\mathrm{II}}$, which has a greater tendency to be retained at the point of entry (Jackson, 1998; Petráš et al., 2012). In regard to previous reflections, it may be supposed that mercury accumulated in trees biomass growing on alluvial deposits originates from soil water environment and not from atmospheric deposition. We further assume that $\mathrm{Hg}$ is input to trunks of trees by the roots, or by the lateral movement of $\mathrm{Hg}$ deposited on the outside of the tree bark, especially in the lower part influenced by floodwater.

Our results show that $\mathrm{THg}$ deposition through litterfall depends on amount of litterfall and is independent on $\mathrm{THg}$ concentration in litterfall. Similar conclusions are reported by Schwesig and Matzner (2000) and Lee et al. (2000) who studied deposition in temperate and boreal zone. By contrast, SilvaFilho et al. (2006) studied fluxes of THg through litterfall in tropical rainforests and attached importance to THg concentration in litterfall. Likewise also tree species composition of forest affects THg deposition by litterfall. Lee et al. (2000) stated that flux of $\mathrm{THg}$ through litterfall represents $17 \mu \mathrm{g}$. $\mathrm{m}^{-2} \cdot \mathrm{yr}^{-1}$ in pine (Pinus sylvestris) forest and in deciduous forests Rea et al. (2002) estimated annual Hg input to forest topsoil as $11.4 \pm 2.8 \mu \mathrm{g} \cdot \mathrm{m}^{-2}$ of $\mathrm{Hg}$. The highest $\mathrm{Hg}$ input by litterfall is noticed in tropical rainforests, $122 \mu \mathrm{g} \cdot \mathrm{m}^{-2} \cdot \mathrm{yr}^{-1}$ (SilvaFilho et al., 2006). Data from temperate zone German forests show litterfall THg flux in coniferous and deciduous (Quercus petraea and Fagus sylvatica) forests, $16 \mu \mathrm{g} \cdot \mathrm{m}^{-2} \mathrm{Hg}$ and 32 $\mu \mathrm{g} \cdot \mathrm{m}^{-2} \mathrm{Hg}$, respectively (Schwesig and Matzner, 2000). Higher annual flux of mercury to soil by litterfall in mixed forest was stated by St. Louis et al. (2001) who determined about $14 \pm 4.0$ $\mu \mathrm{g} \cdot \mathrm{m}^{-2}$ and $7.2 \pm 1.0 \mu \mathrm{g} \cdot \mathrm{m}^{-2}$ in upland forests and coniferous forest, respectively.

Our results show that the throughfall flux is more dominant than litterfall what is in contradiction to several studies (Blackwell and Driscoll, 2015a; Lee et al., 2000; Rea et al., 1996; Rea et al., 2001; Schwesig and Matzner, 2000; 2001) that report litterfall as main $\mathrm{Hg}$ flux into forest floor. In North American forests, $\mathrm{Hg}$ in litterfall is more dominant than throughfall $\mathrm{Hg}$ over deciduous canopies due to the larger amounts of litter under these tree species, whereas throughfall is the primary pathway for mercury deposition over coniferous canopies (Wright et al., 2016). This is in line with our findings that THg deposition in litterfall depends only on the amount of litterfall. Studied forests in Slovakia were mixed ones, so the proportion of deciduous and coniferous tree species in forest looks like important factor for considering litterfall $\mathrm{Hg}$ fluxes. Blackwell and Driscoll (2015a) reported that $\mathrm{Hg}$ deposition in litterfall in conifer forests is less predictable than deciduous forest. Because the more needles in the litterfall, the higher uncertainty brings unknown needle age. There are also other factors that affect the proportion between litterfall and throughfall fluxes, e.g. canopy type or meteorological conditions (Bartík et al., 2019; Blackwell and Driscoll, 2015a; Demers et al., 2007; Su et al., 2019).

We suppose that the explanation of THg contribution via litterfall will be more complex and include microclimatic condition in connection with proportion of various mercury forms and species in the atmosphere, PBM as well as forest composition, all which affect litter decomposition. Wang et al. (2016) describe that $\mathrm{Hg}$ concentration in litter biomass increased by 2.2 times over 25 months. The process is affected by degrees of cellulose and hemicelluloses decomposition (e.g. Berg, 2014, Ferreira and Chauvet, 2011), which facilitate the formation of $\mathrm{Hg}$ binding sites (e.g. $\mathrm{O} / \mathrm{N}$ and reduced organic $\mathrm{S}$ groups) in the biomass.

\section{THg in soil and forest soil percolate}

The open space at the MP1 site is located the historic cinnabar mining area. The high concentration of THg in the surface horizon can be caused by the sedimentation of $\mathrm{Hg}$ streamed out from the area of historical mining and subsequently leached to the lower soil horizons.

$\mathrm{THg}$ contents in forest soils at both areas (MP1 and MP2) are higher than $\mathrm{THg}$ concentrations in forest soils in other areas of Slovakia $\left(0.019-0.151 \mu \mathrm{g} \cdot \mathrm{g}^{-1}\right)$ (Dombaiová, 2005; Ollerová et al., 2004). According to Kabata-Pendias and Pendias (2001) the worldwide average $\mathrm{THg}$ concentration in soil is about 0.14 $\mu \mathrm{g} \cdot \mathrm{g}^{-1}$ however, in areas with cinnabar mining activity, these concentrations could reach up to $900 \mu \mathrm{g} \cdot \mathrm{g}^{-1}$ of $\mathrm{THg}$ in soils (Samaniego et al., 2020). In Malachov mining area can be measured up to $88 \mu \mathrm{g} \cdot \mathrm{g}^{-1} \mathrm{Hg}$ in the soil (Matúš, 2005).

There is different course of $\mathrm{THg}$ in soil profile at the MP2. In the forest and in the open area, we measured the highest concentrations in the Bv horizon, so we assume that the source of $\mathrm{THg}$ in the soil in this locality are bedrocks, namely andesites, which contain $0.01 \mu \mathrm{g} \cdot \mathrm{g}^{-1}$ of mercury (Alloway, 1995).

The proportion of this form of mercury in the soil sample may be dominant or comparable to the physical forms of mercury that have been attached to this sample from anthropogenic sources. This immobile form of mercury does not represent an acute hygienic risk or pollution or hazard to biota. From the ecological (as well hygienic) point of view, interesting is mercury bounded in the soil by physical adsorption or is present in soil in another, e.g. in elemental form. These mercury forms are mobile, they have ability to evaporate into the environment, as well as to participate in physicochemical processes in environment (washing out, dissolution due to acid rain, transformation events) (Merva and Zaic, 1997). The environmental risk represents successive release of mobile $\mathrm{Hg}$ forms.

$\mathrm{HgS}$ in cinnabar weathers slowly under the aerobic conditions (Barnett et al., 1997) and during this process the anion $\mathrm{SO}_{4}{ }^{2-}$ and mercury cation $\left(\mathrm{Hg}^{2+}\right)$ are released into soil (Zhang et al., 2001). The raised $\mathrm{Hg}^{2+}$ ion has a high affinity for organic carbon and form stable complexes with organic compounds in the soil (Suchara and Sucharová, 2005). For this reason, Hg in neutral, humus-rich soils is rapidly bound to complexes and this also corresponds to the low availability of $\mathrm{Hg}$ for plants (Štefanidesová et al., 2000). Another source of Hg in the soil may be $\mathrm{Hg}^{0}$ vapours released from cinnabar (Gustin et al., 2002). $\mathrm{Hg}^{0}$ can be released mainly at low temperatures and in oxidizing conditions. Degradation of cinnabar to $\mathrm{Hg}^{0}$ can also be done by microbial activity. Microorganisms can also reduce $\mathrm{Hg}^{2+}$ cations to elemental $\mathrm{Hg}^{0}$ (Ďurža and Khun, 2002), which can represent (in the form of vapours) up to $30 \%$ of total $\mathrm{Hg}$ content in the soil. This form of $\mathrm{Hg}$ dissolves well in the soil solution, especially when oxygen is present. However, the major part of $\mathrm{Hg}^{0}$ evaporates from the soil into the atmosphere (Cibulka et al., 1991).

Kuklova et al. $(2010 ; 2017)$ examined the Hg content in the Slovenský Raj National Park (eastern Slovakia) area. They found that mercury is an indicator of air pollution from anthropogenic sources (through dry and wet deposition of mercury). In the central Spiš region (eastern Slovakia), the highest 
amounts of pollutants get in atmosphere from the factory processing wood and mineral raw materials (Rudňany, a foundry and metal industry in Krompachy). According to Kuklová et al. (2017) maximum of $\mathrm{Hg}$ in soil profiles was found in the Ooh surface humus horizons of Podzols and in Ool and Oof surface humus horizons of Cambisols $\left(1.5-2.3 \mu \mathrm{g} \cdot \mathrm{g}^{-1}\right)$. Amounts of $\mathrm{Hg}$ were strongly decreasing from topsoil $\left(0.2-0.3 \mu \mathrm{g} \cdot \mathrm{g}^{-1}\right.$ in Podzols; $0.6-0.8 \mu \mathrm{g} \cdot \mathrm{g}^{-1}$ in Cambisols) toward subsoil in mineral layers of both soil types. This shows the high microbial activity of the upper horizons of forest soils that significantly contributes to the balance of organic matter and heavy metals in the soil (Gömöryová et al., 2013).

The values of $\mathrm{Hg}$ concentration found in the Slovenský Raj National Park (eastern Slovakia) area are an order of magnitude lower than the concentrations found by us in the historical mining region of cinnabar mines in Malachov.

\section{Hydrobiochemical balance of THg in forest ecosystem}

The topic of adequate modeling of the groundwater contamination by various substances, including heavy metals such as cadmium, mercury and lead has become one of the most important tasks for soil hydrologists in the last decade. The transport of solutes in soils, and its intensification due to the preferential flow (especially macropore flow), plays crucial role when problems related to the groundwater pollution are dealt with (Bai et al., 2019; Navrátil et al., 2015; Vogel et al., 2007).

The input-output balance suggests that both studied forest ecosystems are exposed to higher THg depositions compared to forest ecosystems in Scandinavia (Lee et al., 2000). However, the results are comparable with the research of Schwesig and Matzner (2000).

Throughfall is a significant $\mathrm{THg}$ input into the forest ecosystem. This THg flow is higher by $44 \%$ at the MP1 and by $36 \%$ at the MP2 compared to the THg flow in precipitation in the open area. The difference between $\mathrm{THg}$ deposition in the forest and in the open area (so-called net throughfall) show us the amount of dry deposition in the canopy layer of the forest (Lindberg, 1996; Rea et al., 1996; Rea et al., 2001). Based on this claim, we found that dry $\mathrm{THg}$ deposition was approximately half of wet $\mathrm{THg}$ deposition.

Sometimes dry deposition of $\mathrm{THg}$ may even exceed the size of wet deposition (Munthe et al., 1998). In our localities, THg from dry deposition could come from cross-border transmission and regional sources of $\mathrm{Hg}$ emissions as well as from wind erosion of the upper soil layers.

The THg outputs through the outflow from the $10 \mathrm{~cm}$ soil layer to the lower soil layers represent $33-40 \%$ of the total $\mathrm{THg}$ inputs into the forest. This relatively high proportion of outputs may indicate high THg mobility in soils.

\section{CONCLUSIONS}

We studied THg hydrobiochemical balance in a forest ecosystem within the area affected by historical mining activity in central Slovakia. Compared to a reference monitoring plot in a forest closed to primeval forest National Reserve Badínsky prales.

Besides the natural content of $\mathrm{THg}$ in soil, there are other $\mathrm{THg}$ inputs represent by $\mathrm{THg}$ depositions through precipitation (MP1 $51 \mu \mathrm{g} \cdot \mathrm{m}^{-2}$, MP2 $37 \mu \mathrm{g} \cdot \mathrm{m}^{-2}$ ), throughfall (MP1 74 $\mu \mathrm{g} \cdot \mathrm{m}^{-2}$, MP2 $51 \mu \mathrm{g} \cdot \mathrm{m}^{-2}$ ) and the litterfall (MP1 $27 \mu \mathrm{g} \cdot \mathrm{m}^{-2}$, MP2 $23 \mu \mathrm{g} \cdot \mathrm{m}^{-2}$ ). THg concentration in throughfall is higher compared to precipitation in the open area show us the role of dry deposition on forest canopy. Wet deposition of $\mathrm{THg}$ at studied localities is higher compared to THg deposition in other regions of Europe, what show us the presence of regional and local sources of mercury emissions and / or high share of crossborder $\mathrm{Hg}$ emissions.

Forest ecosystem has ability to capture atmospheric $\mathrm{Hg}$ and thus make new sources of mercury inputs (throughfall and litterfall) into soil. In this case, litterfall does not represent the main THg flux into forest soil but together with throughfall doubles the $\mathrm{THg}$ input compared to open space deposition. Results also show us enrichment of upper forest soil layer $(10 \mathrm{~cm})$ with $\mathrm{THg}$ as a result of input from litterfall.

This study highlighted the importance of forest areas to the biogeochemical cycle of $\mathrm{Hg}$ in addition to the influence of areas close to cinnabar mining even in inactive ones.

Acknowledgements. This research was funded by the SLOVAK RESEARCH AND DEVELOPMENT AGENCY, grant number APVV-18-0347, APVV-19-0340 and APVV-15-0425 and by the SLOVAK SCIENTIFIC GRANT AGENCY, grant number VEGA $1 / 0068 / 19$, VEGA $1 / 0500 / 19$. The authors thank prof. Ol'ga Kontrišová for valuable advice and comments and to Mr. Ing. Vladimír Kríššák for technical assistance in field work and measurements.

\section{REFERENCES}

Alloway, B.J., 1995. Heavy Metals in Soils. $2^{\text {nd }}$ ed. Blackie Academic and Professional, Glasgow, London, 339 p.

Bai, B., Zhai, Z., Rao, D., 2019. The seepage transport of heavy metal $\mathrm{Pb}^{2+}$ through and column in the presence of silicon powders. Journal of Hydrology and Hydromechanics, 67, 4, 349-358.

Barnett, M.O., Harris, L.A., Turner, R.A., Stevenson, R.J., Henson, T.J., Melton, R.C., Hoffnan, D.P., 1997. Formation of mercury sulfide in soil. Environmental Science and Technology, 31, 3037-3043.

Bartík, M., Holko, L., Jančo, M., Škvarenina, J., Danko, M., Kostka, Z., 2019. Influence of mountain spruce forest dieback on snow accumulation and melt. Journal of Hydrology and Hydromechanics, 67, 1, 59-69.

Beneš, S., 1994. Content and balance of elements in environment. Part II. Ministerstvo zemědělství České republiky, Prague, 159 p. (In Czech.)

Berg, B., 2014. Decomposition patterns for foliar litter - A theory for influencing factors. Soil Biol. Biochem., 78, 222232.

Blackwell, B.D., Driscoll, C.T., 2015a. Deposition of mercury in forests along a montane elevation gradient. Environ. Sci. Technol., 49, 5363-5370.

Blackwell, B.D., Driscoll, C.T., 2015b. Using foliar and forest floor mercury concentrations to assess spatial patterns of mercury deposition. Environmental Pollution, 202, 126-134.

Bublinec, E., Pichler, V., (Eds.), 2001. Slovak primeval forests - diversity and conservation. Institute of Forest Ecology, Zvolen, Slovakia, $196 \mathrm{p}$.

Cibulka, J. et al., 1991. Lead, Cadmium and Mercury Movement in Biosphere. Academia, Prague, 427 p. (In Czech.)

Cole, A.S., Steffen, A., Eckley, C.S., Narayan, J., Pilote, M., Tordon, R., Graydon, J.A., St. Louis, V.L., Xu, X., Branfireun, B.A., 2014. A survey of mercury in air and precipitation across Canada. Patterns and trends. Atmosphere, 5, 635-668.

De Vries, W., Schütze, G., Lofts, S., Tipping, E., Meili, M., Römkens, P.F.A.M., Groenenberg, J.E., 2005. Calculation of critical loads for cadmium, lead and mercury. Background 
document to a Mapping manual on critical loads of cadmium, lead and mercury. Alterra - report 1104. Alterra, Wageningen, $143 \mathrm{p}$.

Demers, J.D., Driscoll, C.T., Fahey, T.J., Yavitt, J.B., 2007. Mercury cycling in litter and soil in different forest types in the Adirondack region, New York, USA. Ecological Applications, 17, 5, 1341-1351.

Dombaiová, R., 2005. Mercury and methylmercury in plants from differently contaminated sites in Slovakia. Plant, Soil, and Environment, 51, 456-463.

Downs, S.G., Macleod, C.L., Lester, J.N., 1998. Mercury in precipitation and its relation to bioaccumulation in fish: A literature review. Water Air and Soil Pollution, 108, 149187.

Ďurža, O., Khun, M., 2002. Environmental geochemistry of some heavy metals. Univerzita Komenského, Bratislava, Slovakia, pp. 61-70. (In Slovak.)

Faïn, X., Obrist, D., Pierce, A., Barth, C., Gustin, M.S., Boyle, D.P., 2011. Whole-watershed mercury balance at Sagehen Creek, Sierra Nevada, CA. Geochim. Cosmochim. Acta, 75, 9, 2379-2392.

Ferreira, V., Chauvet, E., 2011. Future increase in temperature more than decrease in litter quality can affect microbial litter decomposition in streams. Oecologia, 167, 1, 279-297.

Fu, X.W., Zhang, H., Yu, B., Wang, X., Lin, C.J., Feng, X.B., 2015. Observation of atmospheric mercury in China. A critical review. Atmospheric Chemistry and Physics, 15, $16,9455-9476$.

Gömöryová, E., Střelcová, K., Škvarenina, J., Gömöry, D., 2013. Responses of soil microorganisms and water content in forest floor horizons to environmental factors. European Journal of Soil Biology, 55, 71-76.

Grigal, D.F., 2003. Mercury sequestration in forests and peatlands. A review. Journal of Environment Quality, 32, 2, 393-405.

Gustin, M.S., Stamenkovic, J., 2005. Effect of watering and soil moisture on mercury emissions from soils. Biogeochemistry, 76, 215-232.

Gustin, M.S., Biester, H., Kim, C.S., 2002. Investigation of the light-enhanced emission of mercury from naturally enriched substrates. Atmospheric Environment, 36, 3241-3254.

Gustin, M.S., Engle, M., Ericksen, J.A., Lyman, S., Stamenkovic, J., Xin, M., 2006. Mercury exchange between the atmosphere and low mercury containing substrates. Appl. Geochem., 21, 1913-1923.

Hančinský, L., 1972. Forest Types of Slovakia. Príroda, Bratislava, Slovakia, 307 p. (In Slovak.)

Hlavčová, K., Szolgay, J., Kohnová, S., Horvát, O., 2009. The limitations of assessing impacts of land use changes on runoff with a distributed hydrological model. Case study of the Hron River. Biologia, 64, 3, 589-593.

Jackson, T.A.,1998. Mercury in aquatic ecosystems (Chapter 5). In: Langston, W.J., Bebianno, M.J. (Eds.): Metal Metabolism in Aquatic Environments. Chapman \& Hall, London, pp. 77-158.

Jaloviar, P., Saniga, M., Kucbel, S., Pittner, J., Vencurik, J., Dovciak, M., 2017. Seven decades of change in a European old-growth forest following a stand-replacing wind disturbance. A long-term case study. Forest Ecology and Management, 399, 197-205.

Kabata-Pendias, A., Pendias, H., 2001. Trace Elements in Soils and Plants. $3^{\text {rd }}$ ed. CRC Press, Florida, 403 p.

Kolka, R.K., Grigal, D.F., Nater, E.A., Verry, E.S., 2001. Hydrologic cycling of mercury and organic carbon in a forested upland-bog watershed. Soil Sci. Soc. Am. J., 65, 897-905.
Kucbel, S., Jaloviar, P., Saniga, M., Vencurik, J., Klimaš, V., 2010. Canopy gaps in an old-growth fir-beech forest remnant of Western Carpathians. European Journal of Forest Research, 129, 3, 249-259.

Kuklová, M., Kukla, J., Hnilička, F., 2010. The soil-to-herbs transfer of heavy metals in Spruce ecosystems. Polish Journal of Environmental Studies, 19, 6, 1263-1268.

Kuklová, M., Hniličková, H., Hnilička, F., Pivková, I., Kukla, J., 2017. Toxic elements and energy accumulation in topsoil and plants of spruce ecosystems. Plant, Soil and Environment, 63, 9, 402-408.

Lee, Y.H., Bishop, K.H., Munthe, J., 2000. Do concepts about catchment cycling of methylmercury and mercury in boreal catchments stand the test of time? Six years of atmospheric inputs and runoff export at Svartberget, northern Sweden. Science of Total Environment, 260, 11-22.

Lindberg, S.E., 1996. Forests and the global biogeochemical cycle of mercury: the importance of understanding air vegetation exchange process. In: Baeyens, W., Ebinghaus, R., Vasiliev, O. (Eds.): Global and Regional Mercury Cycles: Sources, Fluxes and Mass Balances. Kluwer Academic Publishers, Dordrecht, pp. 359-380.

Lindberg, S.E., Meyers, T., Taylor, G., Turner, R., Schroeder, W., 1992. Atmosphere-surface exchange of mercury in a forest - results of modeling and gradient approaches. Journal of Geophysic Research, 97, 2519-2528.

Malcom, E.G., Keeler, G.J., Lawson, S.T.; Sherbatskoy, T.D., 2003. Mercury and trace elements in cloud water and precipitation collected on Mt. Mansfield, Vermont. J. Environ. Monitoring, 5, 4, 584-590.

Matúš, R., 2005. Migration of trace elements $\mathrm{Hg}$, As and $\mathrm{Sb}$ in Malachov ore field. Vodohospodársky spravodajca, 5-6, 1215. (In Slovak.)

Merva, M., Zaic, J., 1997. Mercury forms in soil from ecology point of view. Acta Montanistica Slovaca, 2, 113-118. (In Slovak.)

Mind'áš, J., Škvarenina, J., 2001. Climate. In: Bublinec, E., Pichler, V. (Eds.): Slovak primeval forests - diversity and conservation. Institute of Forest Ecology, Zvolen, Slovakia, pp. 99-104.

Munthe, J., Pleijel, K., Iverdfeldt, A., Kruger, O., Petersen, G., 1998. Atmospheric deposition of mercury in the Nordic countries at different scenarios of reduced antropogenic emissions in Europe. Swedish Environmental Research Institute, Stockholm.

Nair, U.S., Wu, Y., Holmes, C.D., Ter Schure, A., Kallos, G., Walters, J.T., 2013. Cloud-resolving simulations of mercury scavenging and deposition in thunderstorms. Atmos. Chem. Phys., 13, 19, 10143-10157.

Navrátil, T., Shanley, J., Rohovec, J., Oulehle, F., Krám, P., Matoušková, Š., Tesař, M., Hojdova, M., 2015. Mercury in stream water at five Czech catchments across a $\mathrm{Hg}$ and $\mathrm{S}$ deposition gradient. Journal of Geochemical Exploration, $158,201-211$.

Ollerová, H., Kontrišová, O., Marušková, A., Kontriš, J., 2004. Mercury content in selected herbs and soil on the transect in the Žiarska kotlina (basin). In: Beseda, I. (Ed.): Current problems of environmental contamination in terms of toxicology and ecotoxicology. Part III. FEE TU vo Zvolene, Zvolen, Slovakia, pp. 78-81. (In Slovak.)

Petráš, R., Jamnická, G., Mecko, J., Neuschlová, E., 2012. State of mineral nutrition and heavy metals distribution in aboveground biomass of poplar clones. Polish Journal of Environmental Studies, 21, 2, 447-453.

Pichler, V., Homolák, M., Skierucha, W., Pichlerová, M., 
Ramírez, D., Gregor, J., Jaloviar, P., 2012. Variability of moisture in coarse woody debris from several ecologically important tree species of the Temperate Zone of Europe. Ecohydrology, 5, 4, 424-434.

Rea, A., Keeler, G.J., Scherbatskoy, T., 1996. The deposition of mercury in throughfall and litterfall in the Lake Champlain watershed. A short-term study. Atmospheric Environment, 30, 3257-3263.

Rea, A.W., Lindberg, S.E., Keeler, G.J., 2001. Dry deposition and foliar leaching of mercury and selected trace elements in deciduous forest throughfall. Atmos. Environ., 35, 3453-3462.

Rea, A.W., Lindberg, S.E., Scherbatskoy, T., Keeler, G.J., 2002. Mercury accumulation in foliage over time in two northern mixed-hardwood forests. Water, Air and Soil Pollution, 133, 49-67.

Samaniego, J., Gibaga, C.R., Tanciongco, A., Rastrullo, R., 2020. Total Mercury in Soils and Sediments in the Vicinity of Abandoned Mercury Mine Area in Puerto Princesa City, Philippines. Appl. Sci., 10, 4599.

Scheer, L', 2007. Biometrics. Technická univerzita vo Zvolene, Zvolen, Slovakia, 334 p. (In Slovak.)

Schwesig, D., Matzner, E., 2000. Pools and fluxes of mercury and methylmercury in two forested catchments in Germany. Science of Total Environment, 260, 213-223.

Schwesig, D., Matzner, E., 2001. Dynamics of mercury and methylmercury in forest floor and runoff of a forested watershed in Central Europe. Biogeochemistry, 53, 181-200.

Silva-Filho, E.V., Machado, W., Oliveira, R.R., Sella, S.M., Lacerda, L.D., 2006. Mercury deposition through litterfall in an Atlantic Forest at Ilha Grae, Southeast Brazil. Chemosphere, 65, 2477-2484.

Šmelko, Š., Wolf, J., 1977. Statistics Methods in Forestry. Príroda, Bratislava, Slovakia, 275 p. (In Slovak.)

St. Louis, V.L., Rudd, J.W.M., Kelly, C.A., Hall, B.D., Rolfhus, K.R., Scott, K.J., Lindberg, S.E., Dong, W., 2001. Importance of the forest canopy to fluxes of methyl mercury and total mercury to boreal ecosystems. Environ. Sci. Technol., 35, 3089-3098.

Stanová, V., Valachovič M. (eds), 2002. Catalog of Slovak biotops. DAPHNE - Institute of Applied Ecology, Bratislava, Slovakia, 225 p. (In Slovak.)

Štefanidesová, V., Seidlerová, J., Dvorská, P., 2000. Contaminated soils and mercury form stable complexes. Kontaminované půdy a rtut' tvoří stabilní komplexy. Odpady, 11, 23-24. (In Czech.)

STN 48 1000. Sampling and preparation of forest soil samples for determination the forest health. (In Slovak.)

STN 48 1001. Sampling of assimilation organs for determination the forest health. (In Slovak.)

Styszko, K., Szramowiat, K., Kistler, M., Kasper-Giebl, A., Samek, L., Furman, L., Pacyna, J., Gołaś, J., 2015. Mercury in atmospheric aerosols: a preliminary case study for the city of Krakow, Poland. Comptes Rendus Chimie, 18, 10, 1183-1191.
Su, L., Xie, Z., Xu, W., Zao, Ch., 2019. Variability of throughfall quantity in a mixed evergreen-deciduous broadleaved forest in central China. J. Hydrol. Hydromech., 67, 3, 225231.

Suchara, I., Sucharová, J., 2005. Mercury in the environment and bioindicated distribution of its fallout in the Czech Republic and in surrounding of Spolana, Neratovice plant. Ochrana ovzduší, 3, 19-24. (In Czech.)

Vido, J., Střelcová, K., Nalevanková, P., Leštianska, A., Kandrík, R., Pástorová, A., Škvarenina, J., Tadesse, T., 2016. Identifying the relationships of climate and physiological responses of a beech forest using the Standardised Precipitation Index: a case study for Slovakia. Journal of Hydrology and Hydromechanics, 64, 3, 246-251.

Vogel, T., Lichner, L., Dusek, J., Cipakova, A., 2007. Dualcontinuum analysis of a cadmium tracer field experiment. Journal of Contaminant Hydrology, 92, 1-2, 50-65.

Wang, X., Lin, C.-J., Lu, Z., Zhang, H., Zhang, Y., Feng, X., 2016. Enhanced accumulation and storage of mercury on subtropical evergreen forest floor: Implications on mercury budget in global forest ecosystems. Journal of Geophysical Research: Biogeoscience, 121, 2096-2109.

Wright, L.P., Zhang, L., Marsik, F.J., 2016. Overview of mercury dry deposition, litterfall, and throughfall studies. Atmos. Chem. Phys., 16, 13399-13416.

Zhang, H., Lindberg, S.E., Marsik, F.J., Keeler, G.J., 2001. Mercury air/surface exchange kinetics of background soils of the Tahquamenon River watershed in the Michigan upper peninsula. Water, Air and Soil Pollution, 126, 151-169.

Zhou, J., Feng, X., Liu, H., Zhang, H., Fu, X., Zhang, Y., 2013. Examination of total mercury inputs by precipitation and litterfall in a remote upland forest of Southwestern China. Atmospheric Environment, 81, 364-372.

Zhou, J., Wang, Z., Zhang, X., Gao, Y., 2017. Mercury concentrations and pools in four adjecent coniferous and deciduous upland forests in Beijing, China. Journal of Geophysical Research: Biogeosciences, 122, 5, 1260-1274.

Zhou, J., Wang, Z., Zhang, X., 2018. Deposition and fate of mercury in litterfall, litter, and soil in coniferous and bradleaved forests. Journal of Geophysical Research: Biogeosciences, 123, 8, 2590-2603.

Zhou, J., Du, B., Shang, L., Wang, Z., Cui, H., Fan, X, Zhou, J., 2020. Mercury fluxes, budgets, and pools in forest ecosystems of China. A review. Environmental Science and Technology, 50, 14, 1411-1450.

Zuśka, Z., Kopcińska, J., Dacewicz, E., Skowera, B., Wojkowski, J., Ziernicka-Wojtaszek, A., 2019. Application of the principal component analysis (PCA) method to assess the impact of meteorological elements on concentrations of particulate matter (PM10): A case study of the mountain valley (the Sącz Basin, Poland). Sustainability, 11, 23, 6740.

Received 15 December 2020 Accepted 27 January 2021 